\title{
Rhinoscopy in three dogs
}

\author{
Case Report \\ Volume: 2, Issue: 2 \\ August 2018 \\ Pages: 53-56
}

\section{Article History}

Received: 31.05.2018

Accepted: 18.07 .2018

Available online: 19.07 .2018

\section{Duygu sezer $^{1} *$, Kemal Altunatmaz ${ }^{1}$}

1. Istanbul University Cerrahpasa, Veterinary Faculty, Surgery Department, Avcilar, Istanbul, Turkey.

DOI: $10.30704 /$ http-www-jivs-net.429334

To cite this article: Sezer, D. (2018). Rhinoscopy in three dogs. Journal of Istanbul Veterinary Sciences, 2 (2), 53-56. Abbreviated Title: J Ist Vet Sci

\section{Introduction}

Rhinoscopy's meaning is the diagnostic examination of nasal cavity with endoscopy. Rhinoscopy is a significant procedure which explores patient's upper airway disorders (Adaszek et al., 2014). It is easy to implement, provides important information, saves patient from invasive rhinotomy and obtains substantial hints with the patient when a diagnosis is reached (Noone, 2001). Furthermore, rhinoscopy provides direct inspection of almost all nasal mucosa surface, and more importantly it provides to have tissue samples to perform cytological, histopathological and microbiological examination. Rhinoscopy simplifies the diagnosis of nasal neoplasia, lympho-plasmocytic rhinitis and differentiation of orofungal and bacterial rhinitis. The best examination of upper airway can be done with using several techniques together; rhinoscopy, bacteriological, cytological, histopathological and diagnostic technique (Clerx et al., 1996; Meler et al., 2008). The of endoscopic examination is more comprehensible in small animals nasal cavity and upper airway disorders, especially in neoplasma, foreign body, anatomic abnormality and some infections (Willard and Radlinsky, 1999; Sapikowski, 2006). Endoscopy of nasal cavity reveals mucosal congestion and existence of mucus in many chronic rhinit cases. Other diagnosis are foreign bodies, nasal polips, granulamatous rhinitis, oronasal fistulas and nasopharyngeal stenosis (Adaszek et al., 2014). Foreign bodies like fishbone and green ear of grain can be removed mechanically by using and endoscopic forceps. Granulomas are prone to bleed but usually stops bleeding in 3-60 minutes (Knotek et al., 2001). Anterior examination of nasal cavity can be done by using a rigid or elastic endoscope. The indications of rhinoscopy includes; persistent unilateral or bilateral nasal discharge, recurrent nose bleedings, progressive nasal discharge, deformation of nasal region, nasal sounds, tenderness of nasal region, 
wheezy respiration, foreign body and suspicion of neoplastic mass (Elie and Sabo., 2006; Venker-Van Haagen., 2005). It also has been reported that detection of bilateral changes and application of systemic antifungal agents in mucotic rhinosinusitis (Sharman., 2010).

This region splits as anterior and posterior rhinoscopy. In anterior rhinoscopy rigid endoscopes varies between 0,30 degrees, with 50 centimeter length and 2-5 $\mathrm{mm}$ of diameter is frequently used. Arthroscopic equipment can be used in this implementation; $2,7 \mathrm{~mm}$ arthroscopes are suitable for many patients and it provides well illumination and good quality of vision (Tappin, 2011). Flexible endoscopes are used less frequently and 6-10 mm ones should be preferred (Marcin et al., 2010). Anterior rhinoscopy; should be moved gently and carefully throughout nasal septum. All three air sections can be examined in this way. Posterior rhinoscopy allow to inspect soft palate, nasopharynx, concha and auditory tube opening. Retrograde (posterior) rhinoscopy is applied in retroflexion; endoscope should be pushed in parallel to oral opening and soft palate through the caudal of pharynx. After entering to soft palate, it should be turned over 90 degrees of angle. However, all manipulations in this region in highly irritant (Tappin, 2011; Knotek., 2000).

The quality of patients rhinoscopy assisted with the history of the patient, clinical examination findings and additional data, blood analysis (CBC -complete blood count- and serum biochemistry), radiological and nasal examination (Marcin et al., 2010; McKiernan, 2001).

Nasal cavity and corona regions mucosal condition (color, moisture, brittleness), blood vessels, foreign body and hypertrophic changes should be considered during rhinoscopy (Marcin et al., 2010; HarcourtBrown, 2006; Tams, 1990; Venker-Van Haagen, 2005).

It was aimed in this study to show the advantages of rhinoscopy in routine examination of upper airways.

\section{Case}

In the present study, a total of 3 dogs of different breeds, age and genders which underwent rhinoscopy were evaluated. Food and water intake of the patients were restricted 8 hours and 1 hour before the induction of anesthesia, respectively and was taken under general anesthesia with propofol. $(8 \mathrm{mg} / \mathrm{kg}$, Propofol , \%1 Fresenius, Germany). The patients weren't intubated because the implementation took short time. Rhinoscopy was performed in lateral or sternal recumbency. (Butorphanol $(0.02 \mathrm{mg} / \mathrm{kg}$, Butomidor, Richter Pharma AG, Austria) was used for analgesia.

In this study, a Weidler branded rigid endoscope with 0-degree angle, $11 \mathrm{~cm}$ lenght, $2.7 \mathrm{~mm}$ diameter was used.

The first case is a 2.5-year-old German Shepherd Dog and was taken to the clinic for epistaxis. As a result of rhinoscopy, bleeding and focal abscesses were seen. Patient came back positive for Ehrlischia and Drofilaria according to blood parasite analysis. (Figure 1)

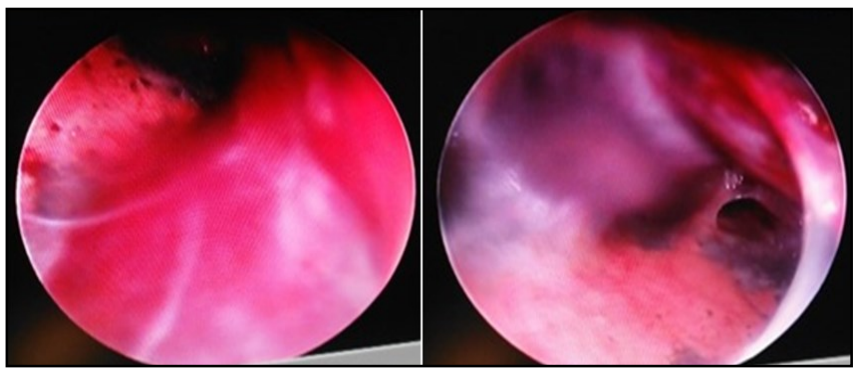

Figure 1. Focus of bleeding (a) and abscess (b) in first case's concha.

The second case is a 2 year old Belgian Shepherd Dog which was brought in to the clinic for unilateral nose bleeding. Foreign body (false barley/ Hordeum murinum) was seen in rhinoscopy and removed by a forceps (Figure 2).

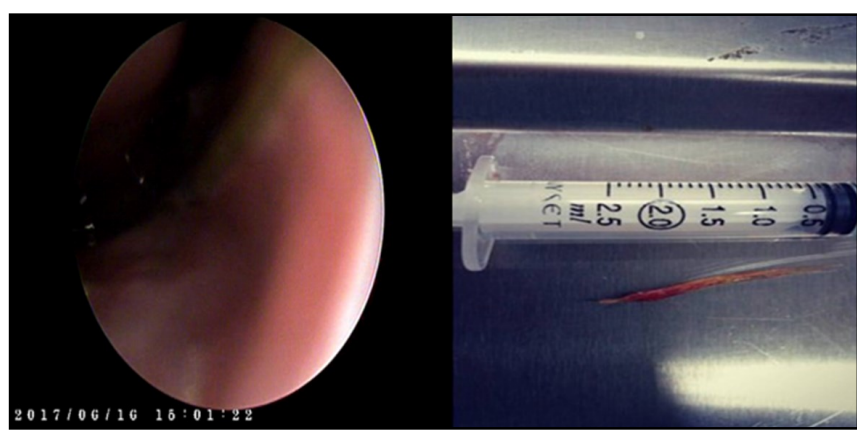

Figure 2. Foreign body's rhinoscopy imaging (a) and false barley (Hordeum murinum) removal via alignment forceps (b) in second case.

The third case is a 1,5-year-old female Pitbull Terrier and admitted to the clinic with unilateral epistaxis and reverse sneezing. A nasal foreign body (wild barley) was detected in rhinoscopy and removed by a foreign body forceps (Figure 3 ). 


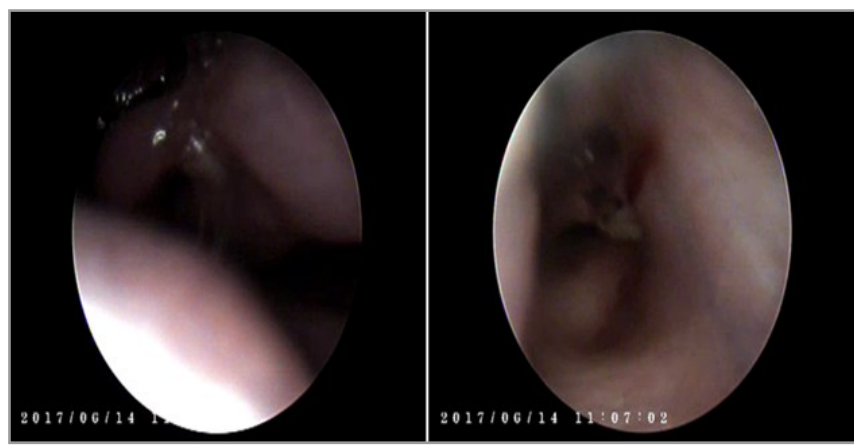

Figure 3. False barley (Hordeum murinum) in cocha (a) and focus of bleeding (b) in third case.

\section{Results and Discussion}

In a study carried out by Knotek et al. (2000 and 2001), foreign bodies can be removed mechanically via forceps and prone to bleeding. In two of in this study two cases a foreign body (false barley) was detected and removed with forceps. Although it has been stated in previous studies (Knotek et al., 2000; Knotek et al., 2001), that the bleeding would stop in half an hour without any implementations. It was

\section{References}

Adaszek, L., Staniec, M., Buczek, K., Winiarczyk, S., Lopuszynski, W., Andrzejmilczak, A. S. , Debiak, P., Klimiuk, P., Wylupek, D., \& Smiech, A. (2014). Appliction of rhinoscopy in the diagnostics of nasal tumors in dogs. Weterynaryjna, 70(1), 54-59.

Clerx, C., Wallon, J., Gilbert, S., Snaps, F., Coignoul, F. (1996) Imprint and brush cytology in the diagnosis of canine intranasal tumors. Journal of Small Animal Practice, 37 (9), 423-427.

Elie, M., \& Sabo, M. (2006). Basics in canine and feline rhinoscopy. Clinical Techniques in Small Animal Practice, 21(2), 60-63.

Harcourt-Brown, N. (2006) Rhinoscopy in the dog 1. Anatomy and techniques. In Practice, Clnical practice, 28 (4), 170-175.

Knotek, Z., Fichtel, T., Husnik, R., \& Benak, J. (2000). Endoscopic diagnostics of chronic diseases of the nasal cavity in dogs. Acta Veterinaria Brno, 69(4), 319-326.

Knotek, Z., Fichtel, T., Kohout, P., \& Benák, J. (2001). Diseases of the nasal cavity in the dog. Aetiology, Symptomatology, Diagnostics. Acta Veterinaria Brno, 70. 73-82.

Marcin, J., Jolanta, S., Krzysztof, K., Maciej, G., Agnieszka, H., applied local adrenaline and tampons in the cases to control the bleeding.

According to the study of Pietra et al. (2010), blood parasites take an important place in epistaxis. Although this study (Pietra et al., 2010) points out that endoscopy is not definitive in blood parasites, the focus of bleeding and abscess that have encountered during rhinoscopy made to think about blood parasites and thoughts were confirmed according to analysis.

Rhinoscopic examination provides some beneficial data in a large scale in patients who were brought to the clinic with unilateral or bilateral epistaxis. Furthermore, it's invasive act is scarcely any when its performed carefully. For this reason, conclude that routine rhinoscopic examination of similar patients is minimally invasive during diagnosis and treatment. As a result; it has been found that rhinoscopy is quite useful in the diagnosis and treatment of most problems encountered in the nasal region.

Kamila, G. S., Józef, N., Vasyl, V., \& Igor, M. (2010) Rhinoscopy in dogs. Науковий вісник Львівського національного університету ветеринарної медицини та біотехнологій ім. ґжицького. Т. 12, 3(1): 323-327. Retrieved from : https://cyberleninka.ru/article/v/ rhinoscopy-in-dogs

McKiernan, B. (2001, August 8- 11) Sneezing and snorting. What should I do? Paper presented at the 26th Congress of the World Small Animal Veterinary Association, Vancouver, British Columbia, Canada.

Meler, E., Dunn, M., \& Lecuyer, M. (2008). A retrospective study of canine persistent nasal disease: 80 cases (19982003). Canadian Veterinary Journal, 49(1), 71-76.

Nicpon J., Kubiak K. (2000). Badanie endoskopowe psów i kotów (Endoscopic examination in dogs and cats). AWA.

Tappin, S. Rhinoscopy in dogs and cats. Retrieved from: https://www.vettimes.co.uk. (2011, March 7).

Venker-Van Haagen, A. J. (2005, May 11-14). Nasal disease and rhinoscopy; fungal disease/neoplasia. Paper presented at the 30th World Congress of the World Small Animal Veterinary Assosiation, Mexico City, Mexico.

Willard, M. D., \& Radlinsky, M. A. (1999) Endoscopic examination of the choanae in dogs and cats: 118 cases (1988-1998). Journal of the American Veterinary Medical Association, 215(9), 1301-1305. 
Noone, K. E. (2001) Rhinoscopy, pharyngoscopy and laryngoscopy. Veterinary Clinics of North America: Small Animal Practice. 31(4), 671-689.

Petite, A. F., \& Dennis, R. (2006). Comparison of radiography and magnetic resonance imaging for evaluating the extent of nasal neoplasia in dogs. Journal of Small Animal Practice, 47(9), 529-536.

Pietra, M., Spinella, G., Pasquati, F., Rashagnoli, N., Bettini G., \& Spadari, A. (2010). Clinical findings, rhinoscopy and histological evaluation of 54 dogs with chronic nasal disease. Journal of Veterinary Science, 11(3), 249-253.

Sapikowski, G. (2006). Endoscopy in the diagnosis of respiratory tract diseases in dogs. Medycyna Weterynaryjna, 62(3). 327-330.
Sharman, M., Paul, A., Davies, D., MacCayt, B., Swinney, G., Barrs, V., Artegas, A., Robertson, D., \& Mansfield, C. (2010). Multi-centre assessment of mycotic rhinosinusitis in dogs: a retrospective study of initial treatment success (1998 to 2008). Journal of Small Animal Practice, 51(8), 423-427.

Tams, T. R. (1990). Small Animal Endoscopy. 1 st ed. St. Louis, US: Mosby Company. 